\title{
Print, Publicity, and Popularity: The Projecting of Sir Balthazar Gerbier, 1642-1662
}

\author{
Jason Peacey
}

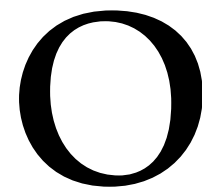

n 18 July 1649, the London bookseller George Thomason received a handwritten note inviting him to the grand opening of an academy at Bethnal Green, outside London's eastern walls, which was to be held on 19 July and where he was promised "good company and a hearty reception." A few weeks later, the reformer Samuel Hartlib received a similar invitation to bring his family to another grand event at the new institution. ${ }^{2}$ The invitations were sent by the academy's founder, Sir Balthazar Gerbier, and his short-lived venture might be regarded as a rather odd footnote to the history of education during the early modern period and be thought to deserve the minimal amount of scholarly attention it received since its collapse twelve months later. ${ }^{3}$ Nevertheless, the interest shown in its operation by Thomason and Hartlib indicates that this scheme represented more than merely an attempt to copy European academies or to emulate Sir Francis Kynaston's Musaeum Minerva of the 1630 s by means of a private facility to educate the elite in the arts of nobility and warfare. It was, in other words, something other than just a display of Gerbier's credentials as a child of the Renaissance. ${ }^{4}$ Gerbier was addressing men

Jason Peacey is senior lecturer in history at University College London. He works on early modern politics, parliaments, and political culture, with a particular interest in print culture and its role in transforming the practices associated with government and popular participation. He would like to thank the editors and the anonymous readers of the Journal of British Studies for their extremely helpful comments and suggestions.

${ }^{1}$ Sir Balthazar Gerbier to George Thomason, 18 July 1649, British Library (BL), E783; H. R. Williamson, Four Stuart Portraits (London, 1949), 52; Michael J. Power, "Sir Balthazar Gerbier's Academy at Bethnal Green," East London Papers 10 (1967): 29; Lita-Rose Betcherman, "Balthazar Gerbier: A Renaissance Man in Early Stuart England” (PhD diss., University of Toronto, 1969), 246.

${ }^{2}$ Invitation to Samuel Hartlib, November 1649, Hartlib Papers (HP) 10/2/30A, Sheffield University Library.

${ }^{3}$ Power, "Sir Balthazar Gerbier's Academy"; Williamson, Four Stuart Portraits, 26-60; Betcherman, "Balthazar Gerbier," chap. 6; J. W. Adamson, Pioneers of Modern Education, 1600-1700 (Cambridge, 1921), 185-89; Richard L. Greaves, The Puritan Revolution and Educational Thought (New Brunswick, 1969), 56; G. H. Turnbull, Hartlib, Dury and Comenius (London, 1947), 57-63.

${ }^{4}$ For suggestions that Gerbier modeled his academy on Kynaston, see Power, "Sir Balthazar Gerbier's

Journal of British Studies 51 (April 2012): 284-307

(C) 2012 by The North American Conference on British Studies.

All rights reserved. 0021-9371/2012/5102-0002\$10.00 
whose activities and intellectual networks indicate a serious interest in educational reform; his academy reveals a novel attitude toward educational provision for both rich and poor, and the creation of a system from which "none are excluded," and he cannot merely be dismissed as a dreamer of "preposterous schemes." However, it is as a means of demonstrating the importance of mid-seventeenth-century communicative practices that this episode really merits scrutiny, for although it is now widely recognized that the period witnessed a "media revolution," relatively little attention has been paid to two crucial developments. ${ }^{6}$ The first relates to contemporary ideas regarding how to integrate print media into communication strategies that also involved techniques from oral and scribal culture and involved the appropriation of different genres for practical and personal purposes, rather than merely in order to demonstrate learning or engage in polemical combat. The second concerns the increasingly interactive nature of the fledgling newspaper medium, something that historians of early journalism have almost entirely overlooked. The real importance of Gerbier's academy, in other words, relates to the way in which, by the late 1640s, a variety of different media and different print genres could be deployed to promote innovative schemes and projects, particularly regarding issues that affected a wider, rather than a narrower, cross-section of the public. ${ }^{7}$

This article demonstrates that Gerbier was a projector who is rather easy to mock until he is considered as a master of communication skills. As Marika Keblusek has noted, Gerbier's life story "reads like a novel, brimming with fantastic adventure, dangerous plots, far-fetched ideas and inevitable failures," and yet it transpires that he had a better appreciation of the potential utility of the media, and of print in particular, than the vast majority of his contemporaries, and as such it is important to examine the degree to which a variety of printed and nonprinted genres became central to the way in which his academy was constructed, promoted, and implemented. ${ }^{8}$ More particularly, a close examination of Gerbier's academy reveals the extent to which print had become a tool for discrete political lobbying in the service of reform, for public advertisement and promotion, and for logistical support in day-to-day operations. Most intriguing of all is Gerbier's recognition of the value of creating a partnership with one of the period's leading journalists, Henry Walker, who served not merely as a member of Gerbier's academic staff but also as publicist and propagandist for his scheme and

Academy," 30. For Kynaston and his academy, see Oxford Dictionary of National Biography (ODNB); The Constitutions of the Musaeum Minervae (London, 1636). For Gerbier's debt to Continental and Renaissance ideas regarding education, see Betcherman, "Balthazar Gerbier," 252-65.

${ }^{5}$ Turnbull, Hartlib, Dury and Comenius, 57; Greaves, Puritan Revolution, 56; Lois Spencer, "The Professional and Literary Connexions of George Thomason," Library, 5th ser., 13 (1958): 102-18; Jeremy Wood, ODNB, s.v. "Gerbier, Sir Balthazar."

${ }^{6}$ Joad Raymond, Pamphlets and Pamphleteering in Early Modern Britain (Cambridge, 2003).

${ }^{7}$ For an appreciation of Gerbier's prolific but under-studied pamphlet output, see Donald Wing, "Sir Balthazar Gerbier," in To Doctor R.: Essays Here Collected and Published in Honor of the Seventieth Birthday of $\operatorname{Dr}$ A. S. W. Rosenbach (Philadelphia, 1946), 241-49. It is, of course, interesting that Kynaston went into print in order to defend his academy from the accusations that he was undermining the universities: Betcherman, "Balthazar Gerbier," 241.

${ }^{8}$ Marika Keblusek, "Cultural and Political Brokerage in Seventeenth-Century England: The Case of Balthazar Gerbier," in Dutch and Flemish Artists in Britain, 1500-1800, ed. Juliette Roding (Leiden, 2003), 74-75. 
curriculum. Gerbier's ill-fated academy demonstrates, therefore, the extent to which free and commercial print, as well as national newspapers, could be used in conjunction with, or in preference to, other forms of communication and integrated into public life. As such, this article seeks to contribute to our understanding of seventeenthcentury journalism, as well as political lobbying, and to the history of noncommercial print and print ephemera. ${ }^{9}$ Gerbier's value as a case study lies in the fact that his correspondence with Hartlib makes visible tactics for the deployment of print that were beginning to find favor with other contemporaries but are extremely difficult for the historian to detect and analyze archivally and methodologically. As someone who was living through a particularly intense phase of the print revolution, a period that witnessed dramatic developments in relation to cheap print, Gerbier was not unique in grappling with communication practices or in experimenting with different media and print genres. Nevertheless, he provides a striking case study that encapsulates the improvisatory developments of the period, and his career demonstrates the need to develop a more nuanced appreciation of early modern print culture and of the role of print. This is particularly important for enhancing our awareness of the utility of print genres and of the difficulties contemporaries faced in calibrating communication strategies. It also highlights the danger of reaching an audience that was either too small or too large in ways that could prove counterproductive or have unintended consequences. However, it will also be possible to use Gerbier as a means of exploring and clarifying contemporary ideas about the democratizing effect of print and about strategies that involved popularity, in terms of courting and exploiting popular support by deploying print genres in the public domain, in ways that fostered political engagement and undermined the arcana imperii. ${ }^{10}$

\footnotetext{
${ }^{9}$ Joad Raymond, The Invention of the Newspaper: English Newsbooks, 1641-1649 (Oxford, 1996); Joseph Frank, The Beginnings of the English Newspaper, 1620-1660 (Cambridge, MA, 1961); Free Print and Non-commercial Publishing since 1700, ed. James Raven (Aldershot, 2000); Ian Archer, "The London Lobbies in the Later Sixteenth Century," Historical Journal 31, no. 1 (1988): 17-44; David Dean, "Pressure Groups and Lobbies in the Elizabethan and Early Jacobean Parliaments," Parliaments, Estates and Representation 11 (1991): 139-52, and "London Lobbies and Parliament: The Case of the Brewers and Coopers in the Parliament of 1593," Parliamentary History 8, no. 1 (1989): 34165; Jason Peacey, "Print Culture and Political Lobbying during the English Civil Wars," Parliamentary History 26, no. 1 (2007): 30-48; Chris R. Kyle, "Parliament and the Politics of Carting in Early Stuart London," London Journal 27, no. 2 (2002): 1-11.

${ }^{10}$ For scholarly interest in the idea of "popularity" in relation to seventeenth-century politics and communication, see Thomas Cogswell and Peter Lake, "Buckingham Does the Globe: Henry VIII and the Politics of Popularity in the 1620s," Shakespeare Quarterly 60, no. 3 (2009): 253-78; Kenneth Fincham and Peter Lake, "Popularity, Prelacy and Puritanism in the 1630s: Joseph Hall Explains Himself," English Historical Review 111, no. 443 (1996): 856-81; Ethan Shagan, "Popularity and the 1549 Rebellions Revisited," English Historical Review 115, no. 460 (2000): 121-33; Thomas Cogswell, "The People's Love: The Duke of Buckingham and Popularity," 211-34; Richard Cust, "Charles I and Popularity," 235-58; and Peter Lake, "Puritans, Popularity and Petitions: Local Petitions in National Context, Cheshire, 1641," 259-89, all in Politics, Religion and Popularity in Early Stuart Britain, ed. Thomas Cogswell, Richard Cust, and Peter Lake (Cambridge, 2002); Peter Lake, "The Politics of Popularity and the Public Sphere: The Monarchical Republic of Elizabeth I Defends Itself," 59-94; and Paul Hammer, "The Smiling Crocodile: The Earl of Essex and Late Elizabethan Popularity," 95115, both in The Politics of the Public Sphere in Early Modern England, ed. Peter Lake and Steven Pincus (Manchester, 2007).
} 
Sir Balthazar Gerbier (1592-1667) is a fairly familiar and colorful figure in early Stuart history, if perhaps a rather peripheral character, probably because he appears to have been something of a dilettante. A Huguenot immigrant from the Low Countries, he rose to prominence as part of the duke of Buckingham's household, and it was for the royal favorite that Gerbier acted as art agent on the Continent and as architectural adviser at home. Gerbier also served in various diplomatic roles, notably in Brussels from 1631 to 1641 , before returning to London as master of ceremonies. ${ }^{11}$ By 1642, however, he had fallen from favor at court for openly criticizing Lord Cottington, ${ }^{12}$ and he faced suspicion and physical violence because of his diplomatic and social contacts with Catholics. ${ }^{13}$ The result was that he fled to France in 1643, only to find himself embarrassed by his daughters' conversion to Catholicism and their disobedient admission into a convent. Gerbier was unable to find a niche among exiled courtiers, for whom his presence caused suspicion and unease. ${ }^{14}$ Nevertheless, Gerbier's earlier life and career are of considerable interest. First, it is tempting to suggest that he learned from Buckingham lessons about media strategies and communicative practices, since the duke was acutely aware of how to use publicity and propaganda (both scribally, in print, and on the stage) in order to boost his reputation, construct his image, and court support. It may have been from Buckingham, in other words, that Gerbier gained an understanding of the politics of popularity. ${ }^{15}$ Second, Gerbier's experiences in the early 1640s reveal more than merely evidence of anti-Catholic hysteria and royalist intrigue. Gerbier ought to be recognized as an important example of "cultural and political brokerage" and as a projector, apparently full of schemes and ideas, even if some of these were considered to be "far-fetched," and even if his life was beset by "inevitable failures." Indeed, it is in connection with these personal and reforming projects that Gerbier is of particular interest, because he proved adept at appropriating print and at integrating both commercial and non-

\footnotetext{
${ }^{11}$ Wood, "Gerbier"; List of Royal Servants, 1641, The National Archives (TNA): Public Record Office (PRO), LC 3/1, fol. 8; Letter books of Sir Balthazar Gerbier, 1631-42, TNA: PRO, SP 105/ 7-18; Balthazar Gerbier to Basil, Lord Feilding, 1637-38, Warwickshire Record Office, CR 2017/ C48/3, 109, 111a, 112a, 114, 121; Calendar of State Papers Domestic (CSPD), 1640-1641, 374; CSPD, 1641-43, 37, 293, 322, 337, 462; HMC Fifth Report, 62; Commons Journals (CJ), ii. 233; Lords Journals $(L J)$, iv. 292. Gerbier's return to England may have been related to his financial problems on the Continent, as well as accusations that he was acting as a spy for France and the Low Countries: CSPD, 1640-41, 150, 265. For the early part of Gerbier's career, see Betcherman, "Balthazar Gerbier," chaps. $1-4$.

${ }^{12}$ CSPD, 1641-43, 38, 40, 41, 46, 47. Williamson, Four Stuart Portraits, 45. Gerbier's disgrace placed him in a difficult financial position, as his petitions from 1642 indicate: CSPD, 1641-43, 65, $73,293,365$.

${ }^{13}$ Power, "Sir Balthazar Gerbier's Academy," 24; A Wicked and Inhumane Plot (London, [5 October] 1642, Wing W2077), sigs. A2-A3.

${ }^{14}$ Sir Richard Browne to Sir Edward Nicholas, 2/12 June 1643, BL, Add. MSS 78194, fol. 19v. Gerbier was granted a pass in December 1642 to travel with the Spanish ambassador to the king and must have left England sometime after that date: $L J$, v. 515. Gerbier's wife and daughters were granted a pass to travel to France in May 1643: LJ, vi. 37. For Gerbier's claim, made in 1648, to have been sent to France with letters of credence from the king in 1643, see "Copy of the declaration made by Sir Balthazar Gerbier," 1648, BL, Add. MSS 78205, fol. 113.

${ }^{15}$ Cogswell and Lake, "Buckingham"; Cogswell, "The People's Love."

${ }^{16}$ Keblusek, "Cultural and Political Brokerage," 74-75, 78.
} 
commercial genres, as well as older, scribal methods, into the tactical armory with which individual schemes were promoted. He was certainly not the first projector to recognize the power of print-Humfrey Baker produced a broadside advertising his services as an educator as early as the 1590s-and Gerbier represents only one example of a broader trend regarding the rise of advertising in the seventeenth century, both before and after the emergence of printed newsbooks. Nevertheless, few predecessors or contemporaries permit such a detailed exploration of the ways in which people exploited the print medium for personal and professional advancement. With Gerbier, in other words, it is possible to explore in some depth the ways in which projectors began to think about print strategically. Indeed, it is hard to avoid the conclusion that it was in Paris that he learned at least some of the lessons that he can be shown to have absorbed regarding the utility of the print media and the uses to which it could be put, only some of which betrayed evidence of popularity. ${ }^{17}$

Some of these lessons seemed to involve echoes of Buckingham's approach to popularity, in terms of demonstrating Gerbier's concern with defending his reputation and promoting his public image. First, therefore, Gerbier realized that print could be used alongside manuscript texts as a device with which to lobby a discrete audience. Having been stung by suggestions that he did not care what became of his offspring, he produced a defense of his position regarding his daughters, which was circulated both scribally and in print in order to win friends among the exiled court, whose assistance and support he craved ahead of crunch talks with prominent Protestant and Catholic divines in Paris. In doing so, Gerbier probably recognized that some of those whom he sought to address would prefer

\footnotetext{
${ }^{17}$ For earlier examples, see Deborah Harkness, The Jewel House: Elizabethan London and the Scientific Revolution (London, 2007), 62-63, 85-86, 95, 97-98, 102, 120-21, 233; H. Baker, Such as are Desirous ([London, 1590?], STC 1209.3). Fragmentary evidence survives regarding similar tactics during the 1640s, including advertisements for Julius Otto's lectures in Edinburgh and handbills by physicians and educators in London. J. Otto, Quod Felix Faustumque sit Ecclesiae Reip et Academiae Edinburgenae (Edinburgh, 1642, Wing, O535a); Nothing Without God ([London], 1647, BL, E526/ 19); C. Ravius, All Gentlemen and Others May be Pleased to Take Notice (London, 1656). For later examples, see David Cressy, "Educational Opportunity in Tudor and Stuart England," History of Education Quarterly 16, no. 3 (1976): 307. For the broader history, see Michael Harris, "Timely Notices: The Uses of Advertising and Its Relationship to News during the Late Seventeenth Century," in News, Newspapers, and Society in Early Modern Britain, ed. Joad Raymond (London, 1999), 141-56; Christine Y. Ferdinand, "Constructing the Frameworks of Desire: How Newspapers Sold Books in the Seventeenth and Eighteenth Centuries," in News, Newspapers and Society, ed. Raymond, 157-75; E. S. Turner, The Shocking History of Advertising (London, 1952), 15-23; Blanche Beatrice Elliott, A History of English Advertising (London, 1962), 21-27; R. B. Walker, "Advertising in London Newsbooks, 1650-1750," Business History 15, no. 1 (1973): 112-30; W. L. F. Nuttall, "Newspapers and Their Advertisements in the Commonwealth," History Today 17, no 7 (July 1967): 460-67; H. C. Whitford, "Exposed to Sale: The Marketing of Goods and Services in Seventeenth Century England, as Revealed by Advertisements in Contemporary Newspapers and Periodicals," Bulletin of the New York Public Library 71, nos. 9-10 (October-November 1967): 496-515, 606-13; Elizabeth Lane Furdell, "Grub Street Commerce: Advertisements and Politics in the Early Modern English Press," Historian 63, no. 1 (2000): 35-53. For handbills, see Elliott, History of English Advertising, 4, 11-13. During the seventeenth century, many such handbills were used to advertise the commercial exploitation of monstrous births, and those with extraordinary physical characteristics, in what represented an early modern "freak show": BL, N.TAB 2026.
} 
to receive a scribal, and thus more personal, text. ${ }^{18}$ Second, he recognized that print could be used to convey such arguments to a much broader public audience, with tracts that may have been printed privately but distributed fairly widely. Gerbier began dabbling with the popular press as early as October 1642, before he left for France, in order to defend himself against the accusations and the threats being made against him in London. In a brief relation of $A$ Wicked and Inbumane Plot . . Against Sir Balthazar Gerbier he explained that his innocency "being well known to many, hath moved him to published the same in print," in order to "disabuse" those who had been misinformed by "scandalous and malicious reports." 19 Subsequently, Gerbier employed a Parisian press to produce a short autobiographical tract, addressed "to all men that loves truth." 20 Third, having appreciated the need to address a wider audience, Gerbier understood the importance of commercial print culture, and as such he began to court publishers to whom his wares could be touted. In other words, Gerbier not only sought to print the tract regarding his daughters but also to secure its commercial publication in order to publicize himself and his cause more widely. On 1 June 1646, therefore, he sent a copy of this brief work to the London publisher and book collector, George Thomason, apologizing for the fact that it was poorly printed- "the French not being able to do it better"-and hoping that he would "think fit to make use of the thing." In other words, Gerbier was trying to persuade Thomason to become his publisher, and he added by way of incentive that "I have other things which perhaps would vent." However, Gerbier went even further in his attempts to spread his message and produced evidence of a fourth dimension to the process by which he learned to exploit print. Gerbier was quick to appreciate that newspapers offered a world of opportunity, perhaps learned from his time spent in Paris, where journalism developed much earlier than in England. ${ }^{21}$ Thomason assiduously noted that another copy of Gerbier's tract and letter had been "directed to Britanicus," one of the leading parliamentarian newspapers of the early 1640s, written by Marchamont Nedham. Gerbier evidently did this in the hope of securing further publicity for his cause. Gerbier appears to have been one of the first to recognize, in other words, that as journalism became increasingly professionalized, editors such as Nedham might be amenable to the commercial opportunities that men like him could offer. ${ }^{22}$ One final lesson that Gerbier learned about the communicative practices, however, was unconnected with the defense and promotion of his image and reputation. Indeed, one of the most intriguing ways in which Gerbier seems to have benefited from Parisian print culture and French journalists involved recognizing that print provided a malleable tool for advancing new ideas and promoting particular projects. Indeed, Gerbier may have more or less consciously

\footnotetext{
${ }^{18}$ Sir Balthazar Gerbier to Richard Steward and Sir Richard Browne, November-December 1646, BL, Add. MSS 78197, fols. 201, 203, 205; A Letter from Sr Balthazar Gerbier Knight, to His Three Daughters Inclosed in a Nunnery at Paris (n.p., n.d. [26 May 1646], Wing, G564; BL, E510/1); copies of tract by Sir Balthazar Gerbier, 1646, BL, Add. MSS 78237, and BL, Harleian MSS 3384.

${ }^{19}$ Wicked and Inhumane Plot, 7.

${ }^{20}$ Baltazar Gerbier Knight to all Men that Loves Truth (n.p., n.d. [Paris, 26 May 1646], Wing, G577; BL, E510/1*).

${ }^{21}$ Howard Mitchell Solomon, Public Welfare, Science and Propaganda: The Innovations of Theophraste Renaudot (Princeton, NJ, 1972).

${ }^{22}$ Sir Balthazar Gerbier to Mercurius Britanicus, 1 June 1646, Thomason Tracts, BL, E510/1.
} 
followed the lead of people like Theophraste Renaudot, the editor of the Gazette, by producing at least ten pamphlets, breviats (printed briefs), and manifestos in French in order to promote a scheme for the reform of banking and credit to relieve the poor. ${ }^{23}$

This evidence indicates that Gerbier had developed a fairly sophisticated approach to both print and manuscript culture by the early 1640s, before the idea for the academy emerged. Indeed, he showed signs of being able to apply and adapt these lessons in different ways and in different circumstances, not least by recognizing the value of using print discretely in support of his projects and of using nonprint media when it was appropriate. Thus, when he introduced his ideas about banking and credit into England in 1646, he did so with a ten-page lobby document addressed to the Long Parliament, which appears not to have been made available for sale but seems rather to have been produced privately for selective publication. ${ }^{24}$ Moreover, quick as he was to employ print, Gerbier did not neglect more traditional methods, and he clearly continued to recognize the value of a well-directed scribal tract, thus demonstrating the truth of recent scholarship regarding the ongoing importance of manuscript circulation. ${ }^{25}$ In 1648 , therefore, a declaration regarding his past career and his current personal and financial plight appears to have been produced exclusively in scribal form, not least for circulation to readers such as Henrietta Maria. ${ }^{26}$ In addition, Gerbier also penned a lengthy manuscript relation in defense of both James I and Charles I (June 1648), which was addressed to the prince of Wales and which too was circulated scribally and selectively, in leather-bound presentation copies. ${ }^{27}$ Nevertheless, such examples became increasingly rare when compared to Gerbier's exploitation of print, whose value he perhaps came to recognize precisely because of his rather insecure position as an exile from England and as a none-too-welcome figure on the fringes of the royal court in Paris. He clearly appreciated that there was a place for conventional pamphlet publication through publishers like Thomason, particularly for someone with a reputation to defend, but he also recognized the utility of print genres such as lobby documents and newspaper adverts for those with schemes to promote.

${ }^{23}$ Remonstrance tres Humble du Chevalier Balthazar Gerbier (Paris, 1643); Exposition du Chevalier Balthazar Gerbier (Paris, 1644); Factum, Touchant les Monts de Piete (1643); Avant-Courer des Montsde-Piete (1643); Suite de l'Avant-Coureur des Monts-de-Piete (1643); Mont de Piete pour le Soutien des Pauvres (1643); Serments que Doivant Prester les Officiers des Monts-de-Piete (1643); Brevet et Lettres Patentes pour l'Establissement des Monts-de-Piete (1643); Manifeste de Chevalier Balthazar Gerbier (1644); Motifs de l'Institution des Monts-de-Piete (n.d.). The first two of these were reprinted in Archives Curieuses de Histoire de France, ed. F. Danjou, 2nd ser. (Paris, 1838), 6:215-26, 233-42. For Gerbier's ideas, which had been developing since the early 1640s, see CSPD, 1640-41, 527; Williamson, Four Stuart Portraits, 44; Betcherman, "Balthazar Gerbier," chap. 5. Gerbier also published in Paris his Relation du Chevalier Balthazar Gerbier (1648).

${ }^{24}$ To the Honourable the Commons of the Realm of England, Assembled in Parliament. Explanation Concerning Certaine Expedients by Which the State of England May Reape Notable Advantage (n.p., 1646, Wing, G578).

${ }^{25}$ Harold Love, Scribal Publication in Seventeenth-Century England (Oxford, 1993); The Uses of Script and Print, 1300-1700, ed. Julia Crick and Alexandra Walsham (Cambridge, 2004).

26 "Copy of the declaration made by Sir Balthazar Gerbier," 1648, BL, Add. MSS 78205, fols. 11316. It may have been this work that Sir Richard Browne sent to Sir Edward Nicholas: Sir Edward Nicholas to Sir Richard Browne, 13/23 March 1648, BL, Add. MSS 78194, fol. 67.

27 “The relation of Sir Balthazar Gerbier," 26 June 1648, Bodleian MS Eng.hist.e.184. For other copies, see BL, Add. MSS 4181; BL, Add. MSS 78238. The latter is a leather-bound pamphlet. 
This nuanced appreciation of the utility of print, when harnessed to the causes and interests of an ambitious individual, was to remain central to Gerbier's career for the rest of his life. Increasingly, however, Gerbier's communication strategy and public relations activities centered upon projecting, rather than upon his reputation, not least in terms of his ideas for an academy in London, to which attention must now turn.

Within weeks of completing his scribal address to Prince Charles, Gerbier began making plans for his return to England and for establishing an academy that would cater for a humble as well as an elite audience. The story of these preparations can be told thanks to a remarkable bundle of correspondence within the papers of Samuel Hartlib, whose reforming zeal Gerbier seems genuinely to have shared. ${ }^{28}$ Beginning in August 1648, such letters provide invaluable insights into Gerbier's appreciation of the value of print and the strategies he devised for its deployment, which involved his need to win support at Westminster from MPs who may have suspected his motives, and his need to reach a nationwide and nonelite audience.

Gerbier may first have come to Hartlib's attention in July 1648, when their mutual friend, the physician Arnold Boate, outlined Gerbier's French schemes. Gerbier was evidently drawn to Hartlib because of the latter's fascination with educational reform. Hartlib, of course, had attempted to run a school in Chichester in the 1630s and had proved active in promoting the ideas of Comenius in the early 1640s, not least through printed tracts. ${ }^{29}$ Indeed, Gerbier professed to have heard about Hartlib from a story in "one of your weekly intelligences" regarding the desirability of a new academy, and, evidently considering himself the ideal man for the job, introduced himself to Hartlib in a letter from Paris in late August 1648, asking him to "consider my proposition, manifested in the paper herewith." ${ }^{30}$ Gerbier professed not to be dissuaded by the "distempers" in England and even argued that it was now more important than ever for children to be educated in England rather than abroad. ${ }^{31} \mathrm{He}$ may also have been anxious to leave a city that he dismissed as a modern Babylon. ${ }^{32}$ Before being able to leave Paris, however, Gerbier relied upon Hartlib for practical assistance. His letters thus reveal concerns regarding the payment of his creditors and the recovery of money owed to him, as well as the problems involved in obtaining a travel pass. ${ }^{33}$ Here, Gerbier's letters indicate awareness of the need to enlist the support of prominent political figures, and he mentioned the earl of Pembroke (for whom his former secretary

\footnotetext{
${ }^{28}$ Power, "Sir Balthazar Gerbier's Academy," 25-27; Betcherman, "Balthazar Gerbier," 244-46. For the best analysis of these papers, see Turnbull, Hartlib, Dury and Comenius, 57-63.

${ }^{29}$ Arnold Boate to Samuel Hartlib, 26 July 1648, HP 58/3A-B. For Hartlib and educational thought and practice, see Mark Greengrass, "Samuel Hartlib and the Commonwealth of Learning," in The Cambridge History of the Book in Britain, vol. 4, 1557-1695, ed. John Barnard and D. F. McKenzie (Cambridge, 2002), 306-8, 317; Greaves, Puritan Revolution; Turnbull, Hartlib, Dury and Comenius.

${ }^{30}$ Sir Balthazar Gerbier to Samuel Hartlib, 27 August 1648, HP 10/2/2A-B. Gerbier may have been referring to the following "editorial": Moderate Intelligencer 49 (5-12 February 1646), 287.

${ }^{31}$ Sir Balthazar Gerbier to Samuel Hartlib, 27 August 1648, HP 10/2/2A-B.

${ }^{32}$ Sir Balthazar Gerbier to Samuel Hartlib, n.d., HP 10/2/44A.

${ }^{33}$ Sir Balthazar Gerbier to Samuel Hartlib, 4 October 1648, 11 October 1648, 24 October 1648, HP 10/2/13B, 14A, 16A, 16B, 18A; Power, "Sir Balthazar Gerbier's Academy," 26-27.
} 
Sidney Bere now worked), as well as Parliament's speaker, William Lenthall, and another leading MP, Denzil Holles. ${ }^{34}$ Gerbier also discussed with Hartlib the possible location of the academy and mentioned any number of more or less glamorous possibilities across Britain before settling on a fairly humble venue in Bethnal Green, where a suitable house became available upon the death of his father-in-law, William Kipp, in late $1648 .^{35}$

Hartlib's most important role, however, stemmed from Gerbier's request that he should assist in the process of enrolling students, by means of approaches to "fathers of families," and it is here that Gerbier's letters prove particularly revealing about his communication strategy. ${ }^{36}$ In effect, Hartlib became the main publicist for the academy scheme, probably because Gerbier recognized someone who was as adept at exploiting the print medium as he was interested in novel ideas and who was comfortable with the idea of promoting projects and schemes through a variety of media. ${ }^{37}$ In his first letter to Hartlib, therefore, Gerbier enclosed the text of his explanation of, and justification for, the academy, and the fact that this was addressed to the "weekly intelligencer" indicates that Hartlib was supposed to secure its insertion in one of the London newspapers. ${ }^{38}$ Gerbier also asked Hartlib to "put it to the press and have the same printed in folio in a fair large letters," namely as a flier to advertise his scheme, doubtless because of dissatisfaction with the quality of the presswork on the printed handbill that he had produced in France. ${ }^{39}$ This work, addressed To all Fathers of Families and Lovers of Knowledge and Virtues, announced Gerbier's intention to establish an academy in England, provided an outline justification for such a venture and an account of its educational aims, and appended practical details for those who wanted further information. ${ }^{40}$ Moreover, Gerbier not only sent Hartlib one hundred copies of this promotional literature but also explained how he wanted them to be used. ${ }^{41}$ First, he wanted them to be directed to influential public figures such as Holles and Lenthall, as well as Sir William Balfour, in order to facilitate the granting of his return to England. ${ }^{42}$ Such direct lobbying of influential grandees had always

\footnotetext{
${ }^{34}$ Sir Balthazar Gerbier to Samuel Hartlib, n.d., HP 10/2/43A. For Bere's connection to Gerbier, and his employment by Pembroke, see CSPD, 1645-47, 500. Gerbier wrote to the earl of Denbigh in December 1645 in the hope of getting a pass and mentioned having already written to Lenthall, to whom he had recently sent a letter regarding his proposals: HMC Fourth Report, 273.

${ }^{35}$ Sir Balthazar Gerbier to Samuel Hartlib, 6 January 1649, 27 August 1648, 28 November 1648, 25 December 1648, 26 December 1648, 24 March 1649, HP 10/2/1A, 2A-B, 21A, 23A, 25A-B, 28A-B; Sidney Bere to Samuel Hartlib, n.d., HP 10/2/45A-46B. For Gerbier and the Kipp family, see Power, "Sir Balthazar Gerbier's Academy," 23, 27. William Kipp's will, written in May 1646, was proved in May 1649 and named his daughter Deborah as beneficiary and Sidney Bere as one of the overseers: London Commissary Court Original Wills, Guildhall Library, MS 9172/53c, fols. 56-57.

${ }^{36}$ Sir Balthazar Gerbier to Samuel Hartlib, 29 August 1648, HP 10/2/6A.

${ }^{37}$ For Hartlib and the media, see Greengrass, "Samuel Hartlib," 317.

${ }^{38}$ Sir Balthazar Gerbier to Samuel Hartlib, 29 August 1648, HP 10/2/6A.

${ }^{39}$ Ibid. For Gerbier's evident haste to return to England, see Sir Balthazar Gerbier to Samuel Hartlib, n.d., HP $10 / 2 / 43 B$.

${ }^{40}$ To all Fathers of Families and Lovers of Knowledge ([Paris?, 1648]), HP 57/2A. This is the only surviving copy of this work, and its poor spelling betrays its origins in a French print shop.

${ }^{41}$ Sir Balthazar Gerbier to Samuel Hartlib, 29 August 1648, HP 10/2/6A; Power, "Sir Balthazar Gerbier's Academy," 25-26.

${ }^{42}$ Sir Balthazar Gerbier to Samuel Hartlib, 29 August 1648, 15 September 1648, 16/26 September 1648, n.d., HP 10/2/6A, 9A, 10A-11A, 43A.
} 
been, and would remain, integral to Gerbier's exploitation of print, and as his plans crystallized in 1649 he was careful to ensure that the authorities were amenable to his plans. ${ }^{43}$ In March 1649, therefore, he sent Hartlib "a quantity of books" to distribute among members of the republican Council of State. ${ }^{44}$ This discrete lobby document, entitled The Most Humble Expression of Sir Balthazar Gerbier, once again combined a brief autobiography with an outline of his proposals, not least in order to remind readers of the position papers they had already received. ${ }^{45}$ Fearful that he would be dismissed for his former court connections, Gerbier was particularly keen to reassure the authorities that his plans were politically inoffensive and that his students would not discuss the wars, "much less ... meddle with any matter of state." ${ }^{46} \mathrm{He}$ wanted, and apparently secured, "the approval of the present authority." 47

There was more to Gerbier's tactics, however, than merely securing official approval. For example, this 1649 tract also served as a fund-raising tool as he appealed to the likes of the Dutch community in London in the summer of $1649 .{ }^{48}$ Most important of all, however, was the utility of such literature as advertising, and with respect to his 1648 flier he explicitly asked Hartlib to "direct store of them to particular noble families" and to ensure that copies should be "dispersed among such noble families as you may find address for." ${ }^{49}$ In fact, Gerbier conceived of his potential audience fairly widely. He asked Hartlib to ensure not merely that copies should be left at Westminster, "where the Parliament sits," and at St. Paul's Cathedral but also that bundles should be sent to the principal inns in towns such as St. Albans and Guildford "and other places." ${ }^{50}$ In another letter, Gerbier instructed Hartlib to send copies to "the principal inns of the towns of remark, to the end that I may discover how the fathers of families will like the said establishment, and how many of them will resolve to have their sons so instructed." Thereafter, Gerbier hoped that Hartlib would "use your best means for the dispersing thereof throughout all the kingdom," and this comment, together with the plan to secure newspaper coverage, indicates the size of Gerbier's intended audience. ${ }^{51}$ Given Gerbier's demonstrable awareness of the different uses to which print could be put and the variety of audiences to which it could be addressed, such comments were clearly fairly deliberate. He was evidently determined to cast

\footnotetext{
${ }^{43}$ The topic and nature of Gerbier's complaint to the Council of State in June 1649 is unclear, although it may have related to the apparent seizure of some of his papers for use in the king's trial, some of which were ordered to be returned to him later in the year; CSPD, 1649-50, 169, 387.

${ }^{44}$ Sir Balthazar Gerbier to Samuel Hartlib, 24 March 1649, HP 10/2/29B.

${ }^{45}$ To the Right Honourable the Parliament and the Councell of State of England. The Most Humble Expression of Sir Balthazar Gerbier (n.p., n.d., n.t.p., [1649], Wing, G581), 4, 5-10.

${ }^{46}$ Ibid., 11.

${ }^{47}$ Ecclesiae Londino-Batavae Archivum. Tomi Tertii. Epistulae et Tractatus, ed. J. H. Hessels, 2 vols. (Cambridge, 1897), 2:2161.

${ }^{48}$ Ibid., 2:2156. In asking for financial backing from the Dutch community in London, Gerbier offering as a bond not merely art works, jewelry, silverware, and 500 copies of one of his books (probably the Interpreter); ibid., 2:2161, 2162. Like all of the capital's best educational institutions, the academy was founded in debt.

${ }^{49}$ Sir Balthazar Gerbier to Samuel Hartlib, 27 August 1648, 29 August 1648, HP 10/2/2A-B; HP $10 / 2 / 6$ A.

${ }^{50}$ Sir Balthazar Gerbier to Samuel Hartlib, 29 August 1648, HP 10/2/6A.

${ }^{51}$ Sir Balthazar Gerbier to Samuel Hartlib, 27 August 1648, HP 10/2/2A-B.
} 
his net widely in order to find potential clients and did more than merely target families within a narrow elite. This almost certainly explains why he arranged for the printing of yet more copies of his leaflets. Thus, when he mentioned "two great packs of printed papers" in September 1648, which had been produced at Dieppe and sent to his father-in-law William Kipp in Bethnal Green, Gerbier explained that he wanted them to be dispersed much more widely. ${ }^{52}$ In early October 1648, moreover, Gerbier expressed frustration that "my friends have been so neglectful in putting other things to the press at London as that I have been constrained to submit myself to unskilful presses at Dieppe," and he stressed that "it is absolutely necessary to advertise fathers of families who have sons (lurking in chimney corners) to dispose to learning." As such, he once again asked Hartlib to help with reprinting his papers in London and in mid-October pleaded with his friend to "let my advertisements to fathers of family be posted and dispersed throughout the kingdom." ${ }^{53}$ It was probably only after writing such comments that Gerbier realized that Hartlib had, in fact, already succeeded in advertising the academy in one of London's more important newspapers, the Moderate Intelligencer. ${ }^{54}$ Such was Gerbier's overpowering ambition that the appearance of this advertisement elicited only a rather ungrateful reply. He asked Hartlib, "why did not you send me what the weekly [Intelligencer] had printed of my design?" and revealed his determination that this should represent merely the beginning of a much more elaborate campaign by inquiring, "can you not get another weekly intelligencer to mention in his pamphlet my intention right?" 55

As such, the role that Gerbier designed for Hartlib in order to publicize the academy extended beyond merely posting leaflets and placing adverts. He also played a key role in publishing the Interpreter of the academy, Gerbier's more detailed account of its purpose and syllabus. The process of producing and printing this work sheds yet more valuable light upon Gerbier's intended audience and clientele, as well as upon his appreciation of the value of the print medium. The Interpreter was an elaborate volume, and Gerbier had very clear ideas about the form it should take. He had sent Hartlib the book's opening section in October 1648, asking that copies might be dispersed, and the entire work was soon printed in London in preparation for a French edition for distribution throughout Europe. ${ }^{56}$ In it, Gerbier repeated the message of the earlier adverts to "fathers of families and lovers of virtue," outlining the merits of his scheme and explaining how to enroll. ${ }^{57}$ By early 1649, this brief tract had been expanded into a much more substantial volume, The Interpreter of the Academie, which was promoted

\footnotetext{
${ }^{52}$ Sir Balthazar Gerbier to Samuel Hartlib, 16/26 September 1648, n.d., HP 10/2/10A-11A, 43A.

${ }^{53}$ Sir Balthazar Gerbier to Samuel Hartlib, 4 October 1648, 11 October 1648, 24 October 1648, HP 10/2/12A, 16A, 18A.

${ }^{54}$ Moderate Intelligencer 182 (7-14 September 1648), 1531-32.

${ }^{55}$ Sir Balthazar Gerbier to Samuel Hartlib, 4 October 1648, HP 10/2/12B, 14B.

${ }^{56}$ Sir Balthazar Gerbier to Samuel Hartlib, 31 October 1648, 28 November 1648, 24 March 1649, HP 10/2/20A, 21A, 28B; Power, "Sir Balthazar Gerbier's Academy," 27. The printed copy of the opening addresses, sent by Gerbier to Hartlib, survive in Hartlib's papers: Sir Balthazar Gerbier, The Interpreter of the Academy (London, 1648), HP 10/2/27/1A-4B. Gerbier mentioned Danzig, Hamburg, Silesia, and Holland. See also "Petit truchement pour ce qui son desireuz d'apprandre les langues," HP 10/2/47A; "Au peres des familles," HP 48A-60B; printed French edition of the Interpreter, HP $10 / 2 / 27 / 5 \mathrm{~A}-8 \mathrm{~B}$.

${ }^{57}$ Intepreter (1648), HP 10/2/27/Al-4, B3, 5, sig. Bii.
} 
by another shorter tract entitled A Most Necessarie Vade Mecum, which had been printed in France. ${ }^{58}$ The Interpreter itself provided readers with the most detailed justification for the academy and the most comprehensive outline of its curriculum, reinforcing Gerbier's protestations that it was to be politically neutral and distinct from existing universities, as well as Kynaston's academy, and insisting that he did not seek a monopoly. ${ }^{59}$

The problem with the Interpreter lies in the way in which it hinted that Gerbier sought an exclusive clientele for his academy, which might suggest that the marketing strategy devised for the new project was somewhat extravagant and aggressive. Certain comments indicated that the target audience was, as Kynaston's had been, restricted to a select group of children from the greater gentry and nobility, and Gerbier stressed that he was designing more than merely "an ABC school for the English tongue" and indeed that English would rarely be spoken, even by the academy's domestic servants. ${ }^{60}$ Readers of both the Interpreter and the adverts that appeared in the Moderate Intelligencer learned, therefore, that Gerbier was concerned with "that which is more dear and useful to a good statesman," and an accomplished gentleman, in terms of academic subjects and skills such as music, dancing, fencing, horsemanship, and painting. ${ }^{61}$ The extended bilingual version of the Interpreter was over two hundred pages long and can scarcely have been cheap. ${ }^{62}$ Moreover, evidence from the supplementary guide printed by Gerbier during the summer of 1649, which may have been circulated more or less privately to potential clients, as well as from subsequent newspaper adverts, indicated that the fees for the rigidly run academy, at $£ 3$ per month for full-time instruction and full-board accommodation, would be fairly substantial. ${ }^{63}$

Such comments suggest that Gerbier was using a populist hammer to crack an elitist nut. However, his print strategy appears much more astute once it is recognized that there was actually much more to his academy than merely the education of the elite. The marketing makes much more sense, in other words, when Gerbier's plans for weekly public lectures are taken into consideration, as they have too rarely been in the past. ${ }^{64}$ This broader vision for the academy, which

\footnotetext{
${ }^{58}$ Balthazar Gerbier, The Interpreter of the Academie (London, 1649, Wing, G563; BL, E783/3); Williamson, Four Stuart Portraits, 53-54; Power, "Sir Balthazar Gerbier's Academy," 30; Balthazar Gerbier, A Most Necessarie Vade Mecum for Such as the State of England Shall Suffer to Travell Abroad (1649). The only known copy of this work survives in the papers of Hartlib, to whom it was evidently sent by Gerbier: HP 10/2/31/1A-8B; Turnbull, Hartlib, Dury and Comenius, 62-63. It reprinted the address to fathers of families from the Interpreter.

${ }^{59}$ Sir Balthazar Gerbier to Samuel Hartlib, 16/26 September 1648, HP 10/2/10A; "Extracts from Sir Balthazar Gerbier letter," 9 September 1648, HP 36/1/18A; Interpreter (1649), 6.

${ }^{60}$ Sir Balthazar Gerbier to Samuel Hartlib, 4 October 1648, n.d., HP 10/2/12A, 43A. For Gerbier's intention of attracting students from the Continent, see Sir Balthazar Gerbier to Samuel Hartlib, 28 November 1648, HP 10/2/21A.

${ }^{61}$ Moderate Intelligencer 182 (7-14 September 1648), 1531-32; Sir Balthazar Gerbier to Samuel Hartlib, 24 October 1648, HP 10/2/18A-B.

${ }^{62}$ Interpreter (1649), 18-203.

${ }^{63}$ To all Fathers of Noble Families and Lovers of Vertue (n.p., n.d., n.t.p., [4 August 1649], Wing, G574; BL, E1377/2), 6-10; Perfect Diurnall 10 (11-18 February 1650, BL, E543/10), sig. K3. Thomason appears to have been sent his copy of the first of these by Gerbier.

${ }^{64}$ It has been suggested that Gerbier modified his curriculum in order to deflect criticism from the universities, not least from men such as John Wallis; see Betcherman, "Balthazar Gerbier," 246; J. W. Stoye, English Travellers Abroad, 1604-1667(London, 1952), 59. For scholarship on the public lectures, see Betcherman, "Balthazar Gerbier," 251; Greaves, Puritan Revolution, 56.
} 
permits him to be placed in a reforming context with which he is infrequently associated and which makes sense of his friendship with Hartlib, can be detected in a range of Gerbier's writings. ${ }^{65}$ An undated letter to Hartlib stressed his determination to "expose to the public" his curriculum regarding "sciences, manly actions and foreign languages" and made clear his plan to include "a public hall, whereunto the poor of the parishes (I mean the sons) may have access to learn gratis." plained that "there shall be an open hall for some of the poor children of the parish, or those that shall be recommended by the supreme authority, to learn gratis such sciences as may be fit for them." It was to this end that the public lectures were devised: "On every Saturday throughout all the year, between two and three the clock in the afternoon, there shall be a public lesson read in the said academy, as well concerning the grounds and rules of the aforesaid languages, as touching the sciences and exercises, which will give much satisfaction to all fathers of families and lovers of virtue." ${ }^{67}$ In August 1649, Gerbier explained to potential customers that "the most exquisite masters or professors, attainable by any reasonable salaries . . . shall be engaged to read weekly, or other, public lectures, whereunto strangers of civil conversation, as well [as] the academists, shall be freely admitted." ${ }^{\prime 8}$ The same message had also been conveyed to the Council of State by Gerbier's lobby documents, where it was explained that "the master or professors shall be engaged to read weekly the Wednesdays in the afternoons public lectures . . both for strangers of civil conversation, as well as the academists." ${ }^{\prime 9}$ This probably explains why Gerbier stressed the rule that students "shall not question one another concerning birth, nor means, nor profession." "70

Crucial to any analysis of Gerbier's communication strategy, therefore, must be an assessment of his plans for public lectures, and this is where his appreciation of the utility of print was tested to the limit. As suggested at the outset, Gerbier sought to ensure that these public lectures were attended by at least some handpicked guests, and as such he was probably very pleased that the entertainments provided on Monday, 30 July 1649-ranging from a Latin lecture to martial games-were attended by "a number of the nobility and other persons of quality," who included the earl of Clare, Sir John Danvers, and Colonel Edward Whalley, as well as "many knights, ladies and gentry." However, this was far from being an exclusive gathering, having been advertised in advance as "public entertainment" and "public exercises." involved the predictability and manageability of his audience, not least once he significantly deepened the integration of print into his operation of the academy by ensuring that his weekly lectures were not just delivered orally but also published

${ }^{65}$ On this aspect of educational reform, see Cressy, "Educational Opportunity," 301-20.

${ }^{66}$ "Extracts from Sir Balthazar Gerbier letter," 9 September 1648, HP 36/1/18B-19A. See Power, "Sir Balthazar Gerbier's Academy," 31.

${ }^{67}$ Interpreter (1649), 4-5.

${ }^{68}$ To all Fathers of Noble Families and Lovers of Vertue (n.p., n.d., n.t.p., [4 August 1649], Wing, G574; BL, E1377/2), 12.

69 To the Right Honourable the Parliament, 8.

${ }^{70}$ Ibid., 11.

${ }^{71}$ Invitation to Samuel Hartlib, November 1649, HP 10/2/30A; Perfect Occurrences 134 (20-27 July 1649, BL, E532/1), 1199 and 135 (27 July-3 August 1649, BL, E532/7), 1205. 
individually, commercially, and cheaply. ${ }^{72}$ This plan had been explained to Hartlib in late March 1649 and involved some twenty lectures, five of which he claimed were already completed or in press. ${ }^{73}$ In order to effect this plan, Gerbier struck a multibook publishing deal with the experienced (and solidly parliamentarian) London stationer, Hannah Allen. A June 1649 edition of the broadside address To all Fathers of Noble Families duly mentioned that a number of treatises "shall be continually at Mistress Allen's shop at the sign of the crown in Pope's Head Alley," 74 and the same message was repeated in the small octavo pamphlet that Gerbier produced for distribution to "fathers of noble families" in August 1649, in order to outline the academy's curriculum and timetable. ${ }^{75}$ The first printed lecture was acquired by Thomason on 30 August, and this was followed quickly by others in subsequent weeks. ${ }^{76}$

These tracts, one of the very earliest examples of educational set texts, indicate that Gerbier was determined to devote at least some of his time toward the education of a much wider group of people. In essence, Gerbier wanted to provide instruction not merely for boarders but also for day boys and for those from far less privileged backgrounds. However, the most significant evidence regarding Gerbier's determination to secure a genuinely popular audience for at least some of the academy's lectures relates to the decision to switch the publishing arm of his operation from Hannah Allen to Robert Ibbitson in late October 1649. Ibbitson, who ran a much more sizable business, had much stronger links with power brokers at Westminster and Whitehall, and he also published newspapers that could be exploited to promote the academy. Previously overlooked, this newspaper coverage ensures that much more is known about the operation of the academy, and about Gerbier's communications strategy, than was once thought. ${ }^{77}$

Ibbitson's new flyer for Gerbier's academy emphasized much more clearly the central importance of free public lectures, as well as that fact that "a competent number of decayed families children, shall be there taught gratis." ${ }^{78}$ Ibbitson also

\footnotetext{
${ }^{72}$ These were based upon the detailed program of study outlined in the bilingual and lavishly illustrated second part of the Intepreter: The Intepreter of the Academie, pt. 2 (London, 1649, BL, E783/ 4), sig. A, 1-91.

${ }_{73}$ Sir Balthazar Gerbier to Samuel Hartlib, 24 March 1649, HP 10/2/28A-B.

${ }^{74}$ To all Fathers of Noble Families, and Lovers of Virtue ([London, June 1649], Wing, G573; BL, 669.f.14/46). There is another copy in the Thomason collection: To all Fathers of Noble Families, and Lovers of Vertue (single sheet, n.p., n.d., Wing, G573; BL, E783/2). The former of these was dated by Thomason 28 June 1648, but this seems to be a mistake for 1649, the approximate date of other items surrounding Gerbier's piece in the same volume.

${ }^{75}$ To all Fathers of Noble Families and Lovers of Vertue (n.p., n.d., n.t.p., [4 August 1649], Wing, G574; BL, E1377/2), 4.

${ }^{76}$ The First Publique Lecture Read at Sir B. Gerbier his Accademy, Concerning Military Architecture, or Fortifications (London, by Gartrude Dawson for Hanna Hallen, [30 August] 1649, Wing, G561; BL, E572/5); The First Lecture of an Introduction to Cosmographie (London, by Gartrude Dawson for Hannah Allen, [11 September] 1649, Wing, G557; BL, E573/5); The First Lecture of Geographie (London, by Gartrude Dawson for Hanna Allen, [11 September] 1649, Wing, G559; BL, E573/6); The First Lecture Concerning Navigation (London, by Gartrude Dawson, [20 September] 1649, Wing, G556; BL, E574/14).

${ }^{77}$ For comments on how little is known about the operation of the academy, see Power, "Sir Balthazar Gerbier's Academy," 31.

${ }^{78}$ To all Fathers and Noble Families and Lovers of Vertue (London, for Ibbitson, [31 October] 1649, Wing, G575; BL, 669.f.14/87).
} 
took over production of "the publique lectures," which were to be sold from his shop in Smithfield, near Hosier Lane, "after they shall have been first read at the academy, where they are composed for the good of the publique."79 At least six of these appeared between November 1649 and March 1650, each bearing a dedication to a prominent public figure, such as John Bradshaw (president of the Council of State), Sir Henry Vane Jr., William Lenthall, Sir Thomas Fairfax, and the Lord Mayor of London. Four of them also bore the imprimatur of Henry Scobell, clerk of Parliament. ${ }^{80}$ Such commercial texts reinforced the message about the free nature of the lectures and probably drew the activities of Gerbier and the location of his establishment to the attention of an even wider audience. ${ }^{81}$ In addition, Ibbitson and Gerbier were also able to produce news releases at short notice, as in the last weeks of 1649, when they produced a sheet addressed To the Lovers of Vertue Attending the Lecture on the 12th Day of December, announcing a change to the order in which forthcoming lectures would be delivered, at the request of "some eminent lovers of the military art," and providing hints as to what would be covered, as well as "summary heads" of the lecture on navigation, which "shall be had in print next week." ${ }^{82}$ What Ibbitson brought to Gerbier's operation was not merely an efficient publishing business and powerful connections within the Rump but also the services of his close associate, the prominent parliamentarian journalist Henry Walker. What this meant in practical terms was that the pages of Ibbitson's newspaper, Severall Proceedings, penned by Walker with the backing of the regime, featured regular updates on the activities of the academy. In mid-November, therefore, readers learned that the academy would spend the winter months in Whitefriars rather than Bethnal Green, "at the house where Dr Chamberlain was used to dwell near the waterside, close by the Countess of Kent's." ${ }^{83}$ Walker also provided regular puffs for recent and forthcoming lectures. In the first week of December, the paper noted that the lectures held on 5 December met "with great applause of a numerous and noble auditory" and also promoted the lectures that would take place the following week, as well as the

\footnotetext{
${ }^{79}$ Ibid.

${ }^{80}$ The Second Lecture, Being an Introduction to Cosmographie (London, for Ibbitson, [30 November] 1649, Wing, G569; BL, E584/5), sigs. A2, A2v; The First Lecture Touching Navigation (London, for Ibbitson, [3 November] 1649, Wing, G560; BL, E584/4), sigs. A2, A2v; The First Lecture of an Introduction to Cosmographie (London, for Ibbitson, [1 December] 1649, Wing, G558; BL, E584/ 6), sigs. A3, A3v; The First Lecture Being an Introduction to the Military Architecture (London, for Ibbitson, 1650, imp. Scobell, Wing, G555), sigs. A2, A2v; The Art of Well Speaking (London, for Robert Ibbitson, 1650, Wing, G539), sigs. A2, A2v; A Publique Lecture on all the Languages, Arts, Sciences, and Noble Exercises, Which are Taught in Sr Balthazar Gerbier's Academy (London, for Ibbitson, [12 March] 1650, Wing, G568; BL, E595/3), sigs. A2, A2v.

${ }^{81}$ The Art of Well Speaking, 1; A Publique Lecture on all the Languages, sig. A2; The First Lecture Touching Navigation, sig. A2v. Lady Eleanor Davies issued a pamphlet in 1649 complaining about the absence of Bible studies from the academy's curriculum, having evidently seen Gerbier's promotional literature: E. Davies, For the Right Noble, Sir Balthazer Gerbier ([London], 1649, Wing, D1989B); E. S. Cope, Handmaid of the Holy Spirit (Ann Arbor, MI, 1992), 148.

${ }^{82}$ B. Gerbier, To the Lovers of Vertue Attending the Lecture ([London, 1649], Wing, T1567B).

${ }^{83}$ Severall Proceedings 7 (9-16 November 1649, BL, E533/24), 68. For the move to Whitefriars, see Power, "Sir Balthazar Gerbier's Academy," 32. For Walker, see J. B. Williams, "Henry Walker, Journalist of the Commonwealth," Nineteenth Century and After 65 (1908).
} 
three earlier talks that were already available in print. ${ }^{84} \mathrm{~A}$ week later, Walker reported the success of the most recent lecture and once again publicized the event planned for Wednesday, 19 December, and this pattern was repeated in succeeding weeks. ${ }^{85}$

What the Walker-Ibbitson newspaper emphasized most noticeably, however, was the free and public nature of the lectures. Readers were told that the academy was open to young men "without exception of age, and at such fit hours as may stand with their conveniency," and it was pointed out that for such as "can not attend the academy, save in the evening, they shall be read unto them even till seven of the clock at night." ${ }^{86}$ Subsequently, Walker also drew attention to the plan for "an academical entertainment of music" on 12 December and, on another occasion, highlighted the fact that the free weekly lectures were held at 3 p.m., "that lovers of virtue may have convenient time to repair thither." On this occasion, he went so far as to add that, since Gerbier's "scope in the erection of the said academy, is for the general improvement of all lovers of virtue," so it had been decreed that "none are excluded." ${ }^{87}$ The program for 26 December was advertised as including "an intermixture of pleasing music," while the lecture on 2 January was apparently "designed for the ladies, and honourable women of this nation, and is to be on the art of well speaking, according as it hath been required by some of those who are desirous thereof." $\$ 8$ On 28 December, Walker repeated this last announcement, having apparently received enquiries regarding the detailed arrangements from "some honourable ladies and virtuous matrons." 89

What is particularly striking about the association between Gerbier, Ibbitson, and Walker was that it involved not merely the ad hoc exploitation of newspapers but, rather, the development of a strategic and systematic partnership that benefited all parties. Through it, Gerbier secured valuable publicity, while Ibbitson had an incentive to promote the lectures because of the projected sales of the published editions. Particularly intriguing, however, is the motivation of Henry Walker, which centered upon his own involvement in the academy, as tutor in Hebrew. Gerbier had probably always envisaged employing the services of a number of tutors, at one point mentioning the possibility of using his own son as a languages master, and the potential for exploiting Walker's skills may have been part of his appeal. ${ }^{90}$ Walker evidently delivered a lecture on 5 December 1649 and drew attention to his subsequent three lectures and their publication in a number of issues of Ib-

\footnotetext{
${ }^{84}$ Severall Proceedings 10 (30 November-7 December 1649, BL, E533/27), 122. For another promotional comments regarding the published lectures, see Severall Proceedings 14 (28 December-4 January 1650, BL, E533/34), 182; Severall Proceedings 15 (4-11 January 1650, BL, E533/36), 196.

${ }^{85}$ Severall Proceedings 11 (7-14 December 1649, BL, E533/28), 138; 12 (14-21 December 1649, BL, E533/30), 147; and 15 (4-11 January 1650, BL, E533/36), 196.

${ }^{86}$ Severall Proceedings 7 (9-16 November 1649, BL, E533/24), 68.

${ }^{87}$ Severall Proceedings 10 (30 November-7 December 1649, BL, E533/27), 122; and 12 (14-21 December 1649, BL, E533/30), 147.

${ }^{88}$ Severall Proceedings 12 (14-21 December 1649, BL, E533/30), 147.

${ }^{89}$ Severall Proceedings 13 (21-28 December 1649, BL, E533/32), 163-64.

${ }^{90}$ Sir Balthazar Gerbier to Samuel Hartlib, 4 October 1648, HP 10/2/12A. The use of a group of tutors was always evident from his comments, which have been overlooked by scholars of the academy, who have assumed that Gerbier planned to teach alone: Williamson, Four Stuart Portraits, 51; Power, "Sir Balthazar Gerbier's Academy," 31.
} 
bitson's paper. ${ }^{91}$ Thus, the involvement of Ibbitson and Walker provided Gerbier not only with a publisher for his lectures and a lecturer for his academy but also a one-stop-shop for an entire media campaign. The publisher of his lecturers was also the proprietor of a newspaper, the lecturer was the newspaper's editor, and both men had powerful connections within the republican government. The sophistication of Gerbier's operation ensured that his message reached about as large an audience as was possible in republican England, in keeping with his vision for an academy that was to be public as well as private, charitable as well as fee paying.

Gerbier's relations with London publishers and journalists provide striking information about the ways in which contemporaries began not merely to appropriate print for personal ends but also to think strategically about how to use different genres in order to reach different audiences. However, such business arrangements also provide ways of exploring how contemporaries struggled with the potential pitfalls of, rather than merely the potential provided by, popular print culture. Here, the association with Henry Walker might be thought to provide the starting point for exploring how Gerbier learned some bitter lessons regarding the effectiveness of the print medium. First, raising the public profile of the academy also brought public scrutiny, which could take the form of politically charged commentary. Walker, of course, was a well-known and not particularly well-liked member of the journalistic fraternity, and his involvement in Gerbier's academy did not go unnoticed by political and personal rivals. One royalist journalist referred to Walker-whom he styled the state's "newsmonger"-playing "Jack Pudding" in Gerbier's "puppet play," and the same author subsequently claimed that Walker did nothing more than "play the fool." 92 The imagery stuck, and in early March 1650, Nedham too noted that his rival "sometimes keeps lectures at Gerbier's puppet play." ${ }^{93}$ Such comments ought perhaps to have convinced Gerbier that not all publicity was good publicity and that his and Walker's personalities were in danger of becoming central to the way in which the academy was perceived. Some apparently suspected that the venture would attract Gerbier's old friends and become a "receptacle of royalists." Second, hints began to emerge that the media hype that Gerbier had generated was a little too powerful and that his publicity seems to have ensured that the academy was overrun with eager students. ${ }^{94}$

As early as December 1649, Henry Walker was forced to advise "honourable" members of the public who were intending to attend a forthcoming lecture that they should "give notice thereof some time before, to the end they may be better accommodated, and a fit place kept for them." He added that coaches approaching

${ }^{91}$ Severall Proceedings 10 (30 November-7 December 1649, BL, E533/27), 122;11 (7-14 December 1649, BL, E533/28), 138; and 12 (14-21 December 1649, BL, E533/30), 148; Walker advertised the printed versions of his "four orations" on Hebrew in early January 1650: Severall Proceedings 15 (4-11 January 1650, BL, E533/36), 196. They appeared as H. Walker, Bereshit, the Creation of the World (London, 1649).

${ }_{92}$ Man in the Moon 37 (2-9 January 1650, BL, E589/8), 296; and 38 (9-16 January 1650, BL, E589/15), 303.

${ }^{93}$ Mercurius Pragmaticus (For King Charls II), pt. 2, no. 44 (26 February-5 March 1650, BL, E594/17), sig. Xx3v.

${ }^{94}$ B. Gerbier, Counsel and Advice (1663), dedication. 
from Water Lane could drive into the courtyard of the academy, "and have room to turn, and there to remain." "T5 That the lecture attracted too sizable an audience, however, is evident from the subsequent decision announced on 4 January 1650, that the lecture would be repeated the following week, "for the satisfaction of such persons of honour as could not at that time have any room to hear, being they came after the set hour, others having taken up the rooms for which they had sent the day before." The undertone of this passage was that it was people of quality who were being kept out by those of rather less exalted status, and Walker emphasized again that "such persons of honour who are pleased to grace the academy with their presence, would vouchsafe to send thither beforehand, that thereupon all possible care may be taken to keep room for them," provided of course that they arrived promptly for a three o'clock start. ${ }^{96}$ On 11 January, however, Walker was again forced to discuss overcrowding at the lectures, saying that, "whereas a great number of persons of honour have been disappointed of convenient access, and room to hear the lectures (and that by the rudeness of some men), all persons of honour, lovers of knowledge, and others (as well mothers as fathers) that are minded to be satisfied of what the academy doth profess, are desired to send in their names the day before for tickets, that they may be secured from such disturbances and just offences of rude men." ${ }^{97}$ Returning to the same theme yet again on 18 January, Walker reported that Gerbier had been forced to push back a week the lecture that was due to have been delivered on mathematics on 16 January, reiterating that "all fit care shall be taken to keep places for all persons of honour and lovers of knowledge that may be pleased to send before for tickets." By this time, Gerbier appears to been having second thoughts about the accessibility of his talks, and Walker was at pains to stress that it was only for the sakes of such persons of honor that the lectures were to be continued, "and not for those unknown, whose savage rudeness knows not how to entertain civility, but have both in words and actions abused that honourable service, which by this free and virtuous exercise is zealously tendered to this nation." 98

Gerbier's academy was now famous but probably for the wrong reasons, and it was perhaps proving difficult to maintain a successful balance of patrons and avoid the danger that a marketing strategy devised to fulfill Gerbier's charitable ambitions would attract large crowds in ways that would deter high-status fee-paying clients. ${ }^{99}$ It was with some glee that royalists mocked the academy's less than genteel audience. One quipped that those who wished to see Henry "Jack Pudding" Walker "eat his custard" should "send beforehand, that room may be kept for them." Another commentator intimated that Gerbier's academy would be ideal for any gentleman "who would needs put off his bachelor's gown, and go wait upon ladies," in order "to learn the art of courting." "Writing as a royalist hack, meanwhile, Nedham alluded to the less elevated members of Gerbier's clientele

\footnotetext{
${ }_{95}$ Severall Proceedings 13 (21-28 December 1649, BL, E533/32), 163-64.

${ }_{96}$ Severall Proceedings 14 (28 December 1649-1644 January 1650, BL, E533/34), 181.

${ }^{97}$ Severall Proceedings 15 (4-11 January 1650, BL, E533/36), 196.

98 Severall Proceedings 16 (11-18 January 1650, BL, E533/38), 209-10.

${ }^{99}$ It is not clear what Gerbier would have made of the fact that Lady Eleanor Davies described the academy as an "intimation of paradise": Davies, For the Right Noble, Sir Balthazar Gerbier, 2.

${ }^{100}$ Man in the Moon 37 (2-9 January 1650, BL, E589/8), 296.

${ }^{101}$ HMC Egmont I, 492.
} 
by mocking the establishment as "the only bawdy house about London, and a place where the vaulting-vermine of state, many of the saints rampant, make a constant academy for procreation." ${ }^{102}$ Gerbier's response was in some ways defiant. In one promotional handbill from December 1649, he asked the public "to take notice that he will not be diverted by whatsoever ignorant and malicious persons may do, or say, in print to the contrary," singling out the author of The Man in the Moon, "who is said to frequent this place." 103 Nevertheless, he took steps to reposition his academy within the market, to focus his efforts on a respectable middling clientele of fee payers, and to find ways of controlling the audience for the free lectures by asking people to reserve places in advance. In mid-February 1650, he placed an advertisement in at least one leading newspaper to reassure some of those members of his audience who may have been alarmed by such stories. Explicitly seeking to satisfy those who "have of late seemed to be misinformed concerning rates at which gentlemen are boarded and taught at the academy," he outlined in detail the fees and the syllabus. Gerbier emphasized that it was only boarders between the ages of sixteen and eighteen who needed to commit themselves for at least three months, stressed that gentlemen "of age" need only commit themselves on a monthly basis, and pointed out that the syllabus could be designed to suit the "genius and capacity" of individual scholars. As a result, it was possible to "diminish or increase their charges accordingly." Perhaps recognizing that his elite students were drifting away, Gerbier seems to have been trying to attract a more modest fee-paying clientele. Nevertheless, he clearly persisted with the idea of free public lectures, albeit with ticketed places reserved for "all honourable persons, sending for them in time." 104 Another advertisement, which Gerbier "desired to be inserted" in the Perfect Diurnall in early March 1650, reinforced the point that the now twice-weekly public lectures would continue and even suggested that when the academy resumed its summer residency in Bethnal Green, he intended to set aside certain days "for demonstration of the practical part of all the services possessed in the academy gratis, for such who have not the means to be at the charge of learning the same." Those who were interested in enrolling for this scheme were asked to do so before mid-April and to demonstrate that they had been "recommended by persons of good and honest repute." 105

It is possible to argue, therefore, that Gerbier's academy was much more of a success than historians have recognized, at least in terms of attracting an audience for his free lectures. ${ }^{106}$ That this was achieved in such a short space of time was surely the result of Gerbier's willingness and ability to exploit the print medium in such dramatic ways, fully integrating the running of his establishment with leading printers, publishers, and journalists. Where his scheme was much less successful was in balancing the different aims of the academy with the different audiences he had in mind, and Gerbier evidently struggled to maintain the interest

\footnotetext{
102 Mercurius Pragmaticus (For King Charls II), pt. 2, no. 44 (26 February-5 March 1650, BL, E594/17, 370.44), sig. Xx3v.

${ }^{103}$ Gerbier, To the Lovers of Vertue Attending.

${ }^{104}$ Perfect Diurnall 10 (11-18 February 1650, BL, E543/10), sig. K3. The basic syllabus would cost 30s. per month, with an additional 30s. for music dancing and fencing. Riding lessons were much more expensive: ibid., sig. K3v.

${ }^{105}$ Perfect Diurnall 13 (4-11 March 1650, BL, E534/16), 109.

${ }^{106}$ Williamson, Four Stuart Portraits, 51-54.
} 
of those high-fee-paying families who funded his operation, while at the same time delivering free lectures. A deeper unresolved tension related to the social status of those whom he sought to attract to his public orations. The failure to resolve such problems probably ensured that Gerbier's academy went into fairly rapid decline. Ibbitson and Walker apparently jumped ship in the spring of 1650, the latter quickly finding new employment as minister at Knightsbridge. ${ }^{107}$ Although one more lecture appeared in print in July 1650, from an obscure press run by Gabriel Bedel, nothing more is heard of the academy after the end of its Whitefriars season. ${ }^{108}$ Whether or not the students and teachers returned to Bethnal Green is unknown, although Bishop Brian Duppa suggested that "the mushroom academy" had now "sunk at Whitefriars." Nevertheless, he suspected that "as long as Sir Balthazar is sure that the major part of men are fools, he cannot despair of keeping the chair and having disciples." 109

Duppa was right, and Gerbier continued to seek an outlet for his talents, albeit he now turned his attention to other schemes. These ventures are nevertheless interesting because Gerbier continued to use print in order to undertake targeted lobbying of the political authorities in both England and the Low Countries and to use both commercial and private printing in order to address a variety of audiences. In 1650, for example, Gerbier produced a printed lobby document regarding a range of ideas that he had proposed to the Rump regime concerning the public records, banking, and the cautionary towns. He evidently hoped to jog the regime into action after his "long and incessant attendance on the leisure of the committee" that had been appointed by the Council of State to receive "such of his tenders as do concern this commonwealth's service." from the same year, on which he embarked with Peter Lely and George Gelders, proposed a series of paintings to depict parliamentarian military victories, to be displayed at Whitehall, which was again presented to MPs in the form of a printed single-sheet lobby document. ${ }^{111}$ As before, these privately printed and discretely circulated works went alongside more public statements, such as the brief pamphlet

\footnotetext{
${ }^{107}$ Walker delivered at least one set-piece sermon before Oliver Cromwell in the summer of 1650: Severall Proceedings 41 (4-11 July 1650, BL, E777/22), 602.

108 The Academies Lecture Concerning Justice (for Gabriel Bedel, [4 July] 1650, Wing, G538; BL, $\mathrm{E} 607 / 5)$, sigs. A2-A3.

109 The Correspondence of Bishop Brian Duppa and Sir Justinian Isham, 1650-1660, ed. Sir Gyles Isham (Northamptonshire Record Society, xvii, 1951), 11-12; Power, "Sir Balthazar Gerbier's Academy," 33. See also HMC Egmont I, 492.

${ }^{110}$ To the Parliament. The Most Humble Remonstrance of Sr Balthtazar Gerbier Kt. (n.p., n.d., n.t.p. [1650], Wing, G580), 1. For his correspondence with Bulstrode Whitelocke in 1652 regarding some of his ideas, see HMC Third Report, 192. For a separate printed lobby regarding the cautionary towns, see To the Supreme Authority the Parliament of the Common-wealth of England. The Humble Remonstrance of Sir Balthazar Gerbier (n.p., n.d., [1651], Wing, G582). In June 1649, Gerbier had been summoned by the Council of State to give testimony regarding the seizure by Dunkirkers of a ship owned by colonial adventurers, perhaps from the days of the Providence Island Company: see CSP Colonial (America and West Indies), 1574-1660, 329.

${ }^{111}$ To the Parliament, the Humble Proposals of Sir Balthazar Gerbier, Peter Lilly and George Gelders (n.p., n.d., [1650), Wing, G579); "Proposal to paint the memorable events of Parliament," 1651, BL, Stowe MSS 184, fol. 283.
} 
that linked his banking and record-keeping schemes to England's trading fortunes and advocated learning from the example of his fellow countrymen in the United Provinces. ${ }^{12}$ Moreover, Gerbier continued to recognize that the success of such schemes involved self-defense as well as self-promotion, and in the face of ongoing suspicion regarding his motives and his allegiance he not only dispatched handwritten letters to Cromwell and the Council recounting his life history and his service to the parliamentarian and republican regimes but also went into print with yet another autobiographical Manifestation "printed for the author." 113 The sense that Gerbier was in tune with the reformers within the Rump regime may have been reinforced by the appearance of another pamphlet advocating schemes for poor relief. ${ }^{114}$

Gerbier's efforts appear to have borne fruit at least insofar as the republican regime was prepared to enter into negotiations with him in 1650 and to consider his petitions in the years that followed. They even appear to have considered employing him in relation to the sale of the late king's goods, doubtless because of his expertise in the art market. ${ }^{115}$ Gerbier's services were also employed in order to place pressure upon the Dutch community in London in July 1652, in the hope of persuading them to petition for peace between the two countries. ${ }^{116}$ The fact that the council also granted him a pass to travel to the Continent, as well as $£ 50$, certainly suggests that he was given other covert diplomatic duties, perhaps in the hope that royalist exiles would not suspect him of being friendly to the republican regime. ${ }^{117}$ By the late 1650 s, Gerbier was replicating his skills with the printing press in order to lobby the Dutch authorities regarding his

${ }^{112}$ Sir B. Gerbier, Some Considerations on the Two Grand Staple-Commodities of England (London, by T. Mab and A. Coules, 1651, Wing, G570), 1-3, 5, 8, and see also A Discovery of Certain Notorious Stumbling-Blocks (London, by T. M., [12 March] 1652, Wing, G553; BL, E656/8).

${ }^{113}$ A Manifestation by Sr Balthazar Gerbier (London, printed for the author, 1651, Wing, G565), 2; Sir Balthazar Gerbier to Oliver Cromwell, 1 March 1652, BL, Add. MSS 32093, fol. 302; "A summary relation of Sir Balthazar Gerbier's proceedings," 1652, BL, Add. MSS 32093, fols. 305-7.

${ }^{114}$ A New Years Result in Favour of the Poore (London, by T. M., [1 January] 1652, Wing, G566; BL, E651/14). In March 1650, Gerbier had announced that, when the academy returned to Bethnal Green, the Whitefriars house would be devoted to the relief of the poor by providing free credit; see Perfect Diurnall 13 (4-11 March 1650, BL, E534/16), 109.

${ }^{115}$ CSPD, 1650, 474; CSPD, 1651, 15; CSPD, 1651-52, 235, 325, 350. The sense emerges that Gerbier was not an easy person with whom to do business or settle personal terms of employment: CSPD, 1651-52, 266.

${ }^{116}$ Ecclesiae Londino-Batavae Archivum, 2:2209-10, 2212.

${ }_{17}$ CSPD, 1651-52, 352; Thomas Birch, ed., A Collection of the State Papers of John Thurloe, 7 vols. (London, 1742), 7:275. For Hyde's comments, see William Dunn Macray, Octavius Ogle, W. H. Bliss, and F. J. Routledge, eds., Calendar of the Clarendon State Papers (CCSP), 5 vols. (Oxford, 18721970), 2:150; State Papers Collected by Edward, Earl of Clarendon (CSP), 3 vols. (London, 1767), 3 : 100. While royalists suspected his involvement in the composition of scurrilous tracts like The Nonesuch Charles-something Gerbier strenuously denied-he was not entirely shunned by them during the 1650s: see The Nicholas Papers, ed. George F. Warner, 4 vols. (Camden Society, 1886-1920), 1:310; CCSP, 2:153, 162, 184, 190; CSP, 3:110; 151, 156. For suspicions regarding Gerbier and his involvement in pamphleteering, see Nicholas Papers, 1:311; CCSP, 2:151; "Earl of Leicester library list," Centre for Kentish Studies, Z45/2, fol. 126v. For Gerbier's denials, see Nicholas Papers, 1:310; CSPD, 1661-62, 78-79. Gerbier certainly published a tract outlining the dangers from evil councillors and corrupt courtiers to various European countries: see Gerbier, Les Effects Pernicieux de Meschants Favoris et Grande Ministres D'Estat (The Hague, 1653). 
project to exploit gold mines in Guiana, ${ }^{118}$ and following the Restoration he used Dutch presses to produce promotional literature regarding such colonial adventures in both English and Dutch, not least in order to make a personal approach to Charles II. ${ }^{119}$ But he also seems to have produced more printed texts for deployment in England. A preacher in Bethnal Green, Richard Mayo, felt compelled to produce a brief printed answer to what he described as a "frivolous" pamphlet and a public accusation by Gerbier regarding the conduct of services in the local church. ${ }^{120}$ After returning to London, Gerbier also seems to have inundated the Privy Council with position papers relating to his various schemes and published advice books relating to some of his areas of expertise, such as the art of building and the perils of Continental travel. ${ }^{121}$

Gerbier's ongoing engagement with print indicates that, as he moved from scheme to scheme, he sought to reflect upon his media strategy and his political tactics, and that his projecting continued to involve experimenting with, and refining, the tactics and tools of his trade. Since his time in Paris in the early 1640s, Gerbier had adapted his ideas about how to use print, by concentrating less upon his own image and reputation and more upon his schemes, by becoming more proficient at lobbying political authorities and power brokers, and by devising noncommercial ways of reaching a broad audience through widespread and free distribution. Indeed, where once his reputational literature had shown signs of becoming more and more public, it subsequently became increasingly discrete, while his public utterances were largely reserved for his reforming projects. Here he disseminated his ideas by oral methods (lectures) as well as by means of printed texts, occasionally using scribal methods when he wanted to reach a highly circumscribed audience but more obviously creating an integrated publicity system centered on newspapers, their editors, and their publishers, in order to reach a national nonelite audience. As such, Gerbier provides an extremely valuable way of approaching one of the most difficult tasks for the historian of early modern political culture, relating to the impact of print and the effectiveness of lobbying, and a useful way of thinking about the lessons that contemporaries were beginning to learn about early modern print media.

In terms of his use of noncommercial print, his targeted political lobbying, and his exploitation of the interactivity of newspapers, Gerbier was far from unique.

118 Tweede deel vande Waeractige (The Hague, 1656); Waerachtige Verklaringe Nopende (The Hague, 1656); Waarachtige Verklaringe vanden Ridder Balthasar Gerbier ([The Hague?], 1657); Derde Verclaringe (The Hague, 1656); Gebedt Van der Ridder Balthazar Gerbier (Amsterdam, 1659). For the story of Gerbier's involvement with these schemes, and wider colonial ventures, see Williamson, Four Stuart Portraits, 56.

${ }^{119}$ Informatie voorde Rechts Geleerde (n.p., [1660]); Sommier Verhael (Cedruckt voor den autheur, 1660); "To the king of great Britain," 1660, BL, 1029.e.8/4; A Sommary Description (printed for Sir Balthazar Gerbier, 1660); Avertissement for Men Inclyned to Plantasions in America (Rotterdam, by Herry Goddaeus, 1660). Gerbier may have been motivated in part by the loss of his position as master of ceremonies: CSPD, 1660-61, 415 .

${ }^{120}$ R. Mayo, An Answer to the Zealous Expressions of Sir Balthazar Gerbier ([London, 1659]). This item, not recorded in Wing, survives in the British Library (C.194.a.632/47). Gerbier's pamphlet does not seem to survive.

${ }^{121}$ CSPD, 1661-62, 78-79; A Brief Discourse Concerning the Three Chief Principles of Magnificent Building (London, 1662); Counsel and Advice to all Builders (London, 1663); The First and Second Part of Counsel and Advice to all Builders (London, 1664); Subsidium Peregrinatibus (Oxford, 1665). 
Indeed, many of his contemporaries were also experimenting with communication strategies in similar ways. ${ }^{122}$ Nevertheless, few serve so well to demonstrate the range and extent of improvisation and experimentation and the speed with which novel tactics emerged or to shed light on the thinking behind media strategies and the reflective way in which contemporaries learned from their experiences. Gerbier's schemes, in other words, are particularly important for revealing the sophistication of his understanding regarding the potential power of print and of the various ways in which it could be exploited in the hope of achieving one's ambitions. While Gerbier never lost sight of the value of traditional scribal media, he also recognized the possibilities offered by a variety of different printed formats, from fliers and lobby documents to commercial pamphlets and adverts. He also provides a rare glimpse into the way people thought about how to deploy different techniques to reach particular audiences and fulfill a variety of goals. Gerbier demonstrates, in other words, the speed with which contemporaries adapted to new circumstances and new developments in both political and print culture, particularly in terms of integrating not merely different media but also different players within the worlds of politics and publishing. At the same time, however, the story of the academy, Gerbier's most ambitious and fully realized scheme, indicates that his appreciation of print's practical power may only have been acquired through bitter experience. The experiment at Bethnal Green demonstrated that aggressive advertising and promotion through the medium of popular print could prove counterproductive, not because people failed to take notice of his message but precisely because large numbers of people had gained access to and been attracted by his ideas. For all that he recognized about the value of print, Gerbier appears to have been taken by surprise by its power and by the consequences of its effectiveness.

Beyond this, Gerbier sheds valuable light on what contemporaries meant by the "politics of popularity" and what implications print had for public culture, not least because he was at pains to deny that he "inclined to popularity" and to insist that he sought to protect the arcana imperii, or secrets of state. ${ }^{123}$ First, he suggests that the term popularity needs to be used with care. It is true that Gerbier was using a range of media to reach a broad audience, that he was seeking to enlist popular support, and that he sought to explain himself to something other than a narrow elite. He was, in other words, employing print and publicity as part of his political and personal strategies that were played out in the public domain. As such, he seems to have much in common with those like Buckingham who were accused of popularity. However, the crucial difference between Gerbier's strategy and that of his former patron was that he was neither courting popular support in a personal capacity nor defending and promoting his reputation, and he was not really using public support in order to justify his schemes. Or rather, a preoccupation with his personal reputation and image became much less obviously central to his communication strategy after the early 1640s. Of course, as someone whose self-confidence probably bordered on insufferable arrogance, Gerbier was concerned about his reputation and, like other self-publicists of his time, the

\footnotetext{
${ }^{122}$ See Jason Peacey, Common Politics: Print and Political Participation in Seventeenth Century England (forthcoming).

${ }^{123}$ Manifestation, 2.
} 
personal and the political were hard to separate in Gerbier's printed texts. He went to some lengths, for example, to ensure that his engraved portrait appeared in his many tracts and pamphlets. ${ }^{124}$ But his goal was not the enhancement of his image or the political exploitation of public support; rather, it was (or at least became) the promotion of his projects. He was interested in popularity in a rather different and more straightforward way, in the sense that he sought widespread backing for and involvement in his schemes and he was reaching out to a nonelite and even humble audience. As such, his media strategy involved achieving the practical goals of the lobbyist and advertiser, rather than an attempt to secure and make political capital out of "the people's love."

Second, and linked to this, Gerbier's communications strategy, and his brand of public relations, did not involve what might be called a democratizing impulse. Gerbier seems genuinely to have been a reformer who was interested in the welfare of the poor and the improvement of the middling and lower orders, and he clearly saw print as a means of educating and empowering a fairly broad public, but he was determined not to increase their political power or to make political life more transparent, as did some of those who engaged in the politics of popularity. ${ }^{125} \mathrm{He}$ advocated a public record office, for example, by reveling in the fact that it would make truth available to the humblest members of society, at least in relation to property transactions. He professed to champion any "lad who can but read" against the vested interests of "the learnedest counsellor of the law." 126 Yet, he saw no contradiction between such transparency in the economic sphere and secrecy regarding matters of state, and his appreciation of the value of print was matched by a concerted defense of the arcana imperii. He argued, therefore, that in a wellordered state people would not "divulge or acquaint the people with . . . such passages as shall remain in the breast of the ruler or rulers in chief," and he bemoaned the way in which royal reputations had been damaged by cheap print and the fact that "pamphlets and weekly intelligences have been multiplied, and so greedily received by the people, to the dishonour both of king and nation." ${ }^{127}$ As we have already seen, he was also at pains to stress that the pupils at his academy would not "meddle with any matter of state." In other words, having observed at close quarters the perils of, and hostility toward, the kind of popularity that Buckingham practiced, and having seen how cheap print could undermine political stability and political hierarchies, Gerbier became a media tactician and print strategist while also demonstrating nervousness about the impact cheap print might have on political culture. He reminds us, therefore, that not everyone at the time equated the media revolution with popular political engagement, participation, and liberation.

${ }^{124}$ Sir Balthazar Gerbier to Samuel Hartlib, 26 December 1648, HP 10/2/25A; Manifestation, 2. See Jason Peacey, "John Lilburne and the Long Parliament," Historical Journal 43, no. 3 (2000): 625-46.

${ }^{125}$ Cogswell, “The People's Love," 217; Lake, “The Politics of Popularity," 87.

126 Some Considerations 3, 8-9.

127 "The relation of Sir Balthazar Gerbier," 25 June 1648, BL, Add. MSS 78238, 64; "The relation of Sir Balthazar Gerbier," 26 June 1648, Bodl. MS Eng.hist.e.184, fols. 7-8. 